\title{
Pulmonary disease from exposure to an artificial aluminium silicate: further observations
}

\author{
A W MUSK,' B D BECK,${ }^{2} \mathrm{H}$ W GREVILLE, ${ }^{1} \mathrm{~J}$ D BRAIN,${ }^{2}$ D E BOHANNON ${ }^{2}$ \\ From the Sir Charles Gairdner Hospital,' Nedlands 6009, Western Australia, and Department of Physiology, ${ }^{2}$ \\ Harvard School of Public Health, Boston, USA
}

\begin{abstract}
A cross sectional analysis of the relation between exposure to an artificial aluminium silicate (alunite residue) and pulmonary function changes has been made in 32 subjects, 17 of whom had been previously reported and in whom there was suggestive evidence of a dose response relation between gas transfer and total silicate exposure. Longitudinal data were also available for nine subjects. No dose effect relation was observed in either analysis and only one of the three subjects previously observed to have an abnormal chest radiograph (the index subject) had deteriorated appreciably. Respirable particles of alunite residue were injected intratracheally into Syrian hamsters. No evidence of pulmonary toxicity was seen as judged by bronchoalveolar lavage measurements of the concentrations lactic dehydrogenase, albumin, and the lambda fraction of gold, and the numbers of macrophages, polymorphonuclear cells, and red blood cells ( $\alpha$-quartz and ferrous oxide were used as positive and negative controls). These results do not support a significant toxic effect of this aluminium silicate on the lungs.
\end{abstract}

There is evidence that at least some non-fibrous silicates (talc and kaolin, for example) may cause pulmonary fibrosis. ${ }^{12}$ The evidence for lung disease resulting from exposure to other silicates uncontaminated by free silica, however, is less consistent. Fuller's earth appears to cause nodular lesions in human lungs which do not result in abnormal function, ${ }^{3}$ and sillimanite may cause diffuse and nodular pulmonary fibrosis in rabbits. ${ }^{4}$ More recently, silicate pneumoconiosis of farm workers in California has been described in which the histology of the lungs showed birefringent silicate particles in association with interstitial inflammation and fibrosis. ${ }^{5}$ The disease was progressive and unresponsive to treatment with corticosteroids. Additionally, an artificial aluminium silicate used for cat litter has been implicated in the production of diffuse fibrosis in a group of workers employed in reclaiming, drying, and packaging it for sale as cat litter in Western Australia. ${ }^{6}$ The index case, who showed diffuse interstitial fibrosis with loosely formed granulomas on biopsy, and two others in this study had abnormal chest radiographs and gas transfer. Within the group there was also a tendency towards a relation between total exposure to the aluminium silicate and gas transfer of the lungs. This study has

Accepted 6 April 1987 now been extended to include additional exposed individuals. Nine of the original subjects have also been reviewed for evidence of radiographic deterioration or further decline in lung function which may have been caused by their exposure. The artificial aluminium silicate has also been tested for its pulmonary toxicity in Syrian golden hamsters.

\section{Subjects}

The previous report described the findings in four women and 13 men from a total of 25 subjects known to have worked with the cat litter up to $1978 .{ }^{6}$ In 1981 and 1984 attempts were made to contact and invite all these subjects to attend for further studies. Additionally, all subjects who were known to have worked with the material since the previous study were also invited. Six men and three women agreed to return to the laboratory for further lung function tests in 1981 or 1984 (between 23 and 71 months after first being studied (table 1)). These included the index case and the other two cases with abnormal chest radiographs and gas transfer. An additional 12 currently exposed men who had been exposed to cat litter only since the initial study in 1978 were included in 1981 or 1984, and three previously exposed men who were not currently exposed also attended in 1984. 
Table 1 Subjects included in studies

\begin{tabular}{|c|c|c|c|c|c|c|}
\hline & \multicolumn{2}{|c|}{ Present in initial study only } & \multicolumn{2}{|c|}{$\begin{array}{l}\text { Present in initial and at } \\
\text { least one follow up study }\end{array}$} & \multicolumn{2}{|c|}{ Present in follow up study only } \\
\hline & $\overline{M e n}$ & Women & Men & Women & Men & Women \\
\hline $\begin{array}{l}\text { Currently exposed } \\
\text { Not currently exposed }\end{array}$ & $\begin{array}{l}7 \\
0\end{array}$ & $\begin{array}{l}0 \\
1\end{array}$ & $\begin{array}{l}5^{*} \\
1\end{array}$ & $\begin{array}{l}0 \\
3 t\end{array}$ & $\begin{array}{r}12 \\
3\end{array}$ & $\begin{array}{l}0 \\
0\end{array}$ \\
\hline
\end{tabular}

*Includes one subject with abnormal radiograph.

tIncludes two subjects with abnormal radiographs.

\section{Methods}

\section{STUDY DESIGN}

This study was designed to re-examine the relation between exposure and evidence of disease in all 28 men and four women seen at least once between 1978 and 1984 in a cross sectional manner as previously reported (table 1). ${ }^{6}$ Longitudinal information was available for nine subjects who were seen on more than one occasion to examine the relation between degree of exposure and rate of deterioration in lung function and chest radiographic appearance. Additionally, experimental results of the response of hamster lungs to the intratracheal injection of the silicate material are reported.

\section{QUESTIONNAIRE}

A symptom questionnaire and smoking and occupational histories were obtained at each visit as previously reported. ${ }^{6}$ An index of total exposure (exposure/months) for each subject was calculated as the product of duration of exposure in months and estimated intensity of exposure $(1=$ light, $2=$ moderate, $3=$ heavy). Intensity of exposure was ranked from a knowledge of the job and location of each person in the plant. No measurements of dust exposure levels were available.

\section{PULMONARY FUNCTION}

Forced expiratory volume in one second $\left(\mathrm{FEV}_{1}\right)$ was obtained from a digital spirometer (Hewlett-Packard, Burlington, Massachusetts). Transfer factor for carbon monoxide $\left(T_{L}\right)$ was measured by the single breath carbon monoxide method. ${ }^{7}$ Effective alveolar volume $\left(V_{A}\right)$ was estimated from the dilution of helium during the measurement of $T_{L}$. Total lung capacity (TLC) and vital capacity (VC) were measured in a body plethysmograph (Emerson, Cambridge, Massachusetts). ${ }^{8}$ Predicted values for pulmonary function studies were obtained from Cotes. ${ }^{9}$

CHEST RADIOGRA PHS

Standard posteroanterior chest radiographs were taken with the tube-object distance of $6 \mathrm{ft}(1.82 \mathrm{~m})$. The usual procedure required $150 \mathrm{kv}$ for $6-10 \mathrm{~m} / \mathrm{sec}$ using a falling load tube current with ionisation chamber automatic exposure (Siemen's Iontomat) and a chest Buckey.

\section{ANIMAL STUDIES}

A respirable fraction of the artificial aluminium silicate was prepared by gravity sedimentation in water, decanting, and filtering of the supernatent through an $8 \mu \mathrm{m}$ Nucleopore filter. The filtrate was lyophilised for the bioassay. Syrian golden hamsters were exposed to saline suspensions of the particles in high $(3.75 \mathrm{mg} / 100 \mathrm{~g}$ body weight) and moderate $(0.75 \mathrm{mg} / 100 \mathrm{~g}$ body weight $)$ doses by intratracheal instillation and sacrificed at one day. Their lungs were lavaged and the lavage fluid characterised using cellular and biochemical indicators of pulmonary damage. These indicators were: $(a)$ changes in the in situ phagocytic ability of pulmonary macrophages; $(b)$ damage to the air blood barrier as shown by increases in albumin and red blood cell numbers; $(c)$ inflammation as shown by increases in polymorphonuclear neutrophils and macrophage numbers, and $(d)$ damage to cells, measured by the concentrations in lung lavage supernatent of lactic dehydrogenase (LDH), a cytoplasmic enzyme and peroxidase, a lysosymal enzyme, in the extracellular supernatent of the lung lavage fluid. This system has been calibrated by using the response to highly toxic $\alpha$-quartz and to non-toxic $\mathrm{Fe}_{2} \mathrm{O}_{3} .{ }^{10}$

\section{Results}

\section{CROSS SECTIONAL EFFECTS OF EXPOSURE ON} CURRENT AND PREVIOUS WORKERS

The mean values of the measured parameters of pulmonary function of all subjects at the time of their most recent study were normal (table 2), although six subjects showed $T_{1}<80 \%$ of the predicted value and four subjects had $\mathrm{T}_{\mathrm{L}} / \mathrm{V}_{\mathrm{A}}<80 \%$ of the predicted value. Only one subject (the index case) showed FEV $<80 \%$ of the predicted value but this was accompanied by a similar reduction in VC and a reduction in TLC. Despite there being 18 current smokers and one exsmoker in the group, there was no evidence of airflow obstruction, the mean levels of $\mathrm{FEV}_{1}$ and $\mathrm{FEV}_{1} / \mathrm{VC}$ 
Table 2 Subject characteristics and lung function: most recent result

\begin{tabular}{|c|c|c|c|c|c|c|c|c|}
\hline No & Age & $\begin{array}{l}\text { Smoking } \\
\text { status }\end{array}$ & $\begin{array}{l}\text { Total } \\
\text { exposure§ }\end{array}$ & $T L C$ & $V C$ & $F E V_{1}$ & $T L$ & $T L / V A$ \\
\hline \multicolumn{9}{|c|}{ Men } \\
\hline $1^{*}$ & 29 & Ex & 8 & 112 & 109 & 113 & 125 & 117 \\
\hline $2 \pm$ & 19 & $\mathbf{N}$ & 24 & 109 & 120 & 114 & 126 & 117 \\
\hline $3 t$ & 19 & $\mathrm{~N}$ & 90 & 93 & 94 & 109 & 106 & 117 \\
\hline $4 t$ & 16 & C & 9 & 123 & 116 & 139 & 130 & 113 \\
\hline $5 \ddagger$ & 41 & $\mathrm{C}$ & 24 & 118 & 122 & 123 & 109 & 100 \\
\hline $6 \pm$ & 16 & $\mathbf{N}$ & 6 & 97 & 93 & 103 & 142 & 160 \\
\hline $7 \ddagger$ & 36 & C & 42 & 89 & 92 & 100 & 113 & 112 \\
\hline $8 \ddagger$ & 34 & C & 96 & 88 & 77 & 80 & 80 & 86 \\
\hline $9 \pm$ & 16 & $\mathbf{N}$ & 18 & 97 & 96 & 92 & 105 & 110 \\
\hline $10 \pm$ & 18 & $\mathbf{N}$ & 54 & 97 & 86 & 109 & 100 & 102 \\
\hline $11 t$ & 18 & C & 98 & 95 & 94 & 93 & 90 & 98 \\
\hline $12 \ddagger$ & 17 & $\mathbf{N}$ & 72 & 103 & 98 & 107 & 104 & 105 \\
\hline $13^{*}$ & 18 & C & 3 & 96 & 92 & 91 & 86 & 89 \\
\hline $14^{*} \ddagger$ & 34 & $\mathbf{N}$ & 36 & 111 & 112 & 117 & 97 & 96 \\
\hline $15^{*} \dagger$ & 20 & $\mathrm{~N}$ & 18 & 105 & 111 & 98 & 113 & 106 \\
\hline $16 * \pm$ & 22 & C & 156 & 104 & 100 & 109 & 96 & 92 \\
\hline $17^{*}$ & 16 & $\mathrm{C}$ & 2 & 86 & 89 & 80 & 79 & 89 \\
\hline $18^{*}$ & 19 & C & 48 & 104 & 93 & 111 & 70 & 67 \\
\hline $19 * \ddagger$ & 37 & $\mathrm{C}$ & 264 & 115 & 116 & 130 & 125 & 113 \\
\hline $20^{*}$ & 15 & $\mathbf{N}$ & 6 & 86 & 91 & 92 & 87 & 100 \\
\hline $21^{*}$ & 18 & C & 24 & 93 & 85 & 100 & 75 & 74 \\
\hline $22^{*}$ & 23 & $\mathbf{N}$ & 24 & 93 & 92 & 96 & 106 & 118 \\
\hline $23^{*} \dagger$ & 20 & $\mathrm{C}$ & 10 & 100 & 106 & 109 & 91 & 89 \\
\hline $24^{* !} \ddagger$ & 47 & C & 216 & 117 & 103 & 117 & 90 & 83 \\
\hline $25 \ddagger$ & 29 & C & 6 & 99 & 98 & 102 & 93 & 94 \\
\hline $26 \pm$ & 34 & C & 54 & 105 & 110 & 112 & 97 & 102 \\
\hline $27 t$ & 20 & C & 11 & 94 & 103 & 113 & 97 & 106 \\
\hline $28 t$ & 23 & $\mathrm{C}$ & 9 & 103 & 108 & 100 & 100 & 106 \\
\hline \multicolumn{9}{|c|}{ Women } \\
\hline $29^{*}$ & 36 & $\mathbf{N}$ & 6 & 96 & 100 & 96 & 86 & 89 \\
\hline $30 * \ddagger$ & 55 & $\mathrm{~N}$ & 144 & 104 & 83 & 123 & 91 & 90 \\
\hline $31 * \pm$ & 57 & C & 252 & 133 & 109 & 111 & 60 & 62 \\
\hline $32 * t \ddagger$ & 49 & $\mathbf{N}$ & 54 & 74 & 54 & 52 & 30 & 72 \\
\hline Mean & $27 \cdot 2$ & & 58.9 & $101 \cdot 2$ & 98.5 & $104 \cdot 3$ & 96.8 & $99 \cdot 2$ \\
\hline SD & $12 \cdot 2$ & & $72 \cdot 7$ & $12 \cdot 0$ & 13.8 & $16 \cdot 2$ & 21.8 & $18 \cdot 6$ \\
\hline
\end{tabular}

*Present 1978/9 survey.

tPresent 1981 survey.

†Present 1984 survey.

$\S$ Sum of (grade of severity $\times$ months exposed) (grade-months).

$\mathrm{C}=$ Current smoker, $\mathrm{Ex}=$ ex-smoker, $\mathrm{N}=$ never smoked.

TLC $=$ Total lung capacity ( $\%$ predicted $)$.

$\mathrm{VC}=$ Vital capacity $(\%$ predicted $)$.

$\mathrm{FEV}_{1}=$ Forced expiratory volume in one second (\% predicted).

$\mathrm{T}_{\mathrm{L}}=$ Transfer factor $(\%$ predicted $)$.

$\mathrm{V}_{\mathrm{A}}=$ Alveolar volume ( $\%$ predicted).

being normal. The average total exposure of the group was $60 \cdot 7 \pm 72 \cdot 1$ grade-months. There was no relation between $T_{L} / V_{A}$ and total exposure as previously suggested $^{6}$ or $\log$ total exposure. The regression coefficient for $T_{L} / V_{A}(\%$ predicted $)$ and total exposure (grade-months) was $-0.08(\mathrm{r}=0.30, \mathrm{p}=0.10)$ and for $T_{L} / V_{A}$ (\% predicted) and $\log$ (total exposure) was $-3.7(\mathrm{r}=0.27, \mathrm{p}=0.14)$. Multiple regression analysis using $T_{L} / V_{A}$ (\% predicted) as the dependent variable showed a significant effect of current smoking status only $(p=0 \cdot 007)$. Chest radiographs of all subjects were reviewed and appeared normal apart from the three subjects (subjects 24, 31, and 32) previously considered abnormal ${ }^{6}$ and in whom there had been no significant change.
LONGITUDINAL EFFECTS OF EXPOSURE

Nine subjects (nos 14, 15, 16, 19, 23, 24, 30,31, and 32) had been studied on more than one occasion with an interval of between 23 and 71 months. The mean annual rate of change of $\mathrm{VC}$ was $+0.8 \pm 0.361$, of $\mathrm{FEV}_{1}+0.01 \pm 0.7 \mathrm{l}$, and of $\mathrm{T}_{\mathrm{L}}+0.27 \pm 0.7 \mathrm{ml} / \mathrm{min} /$ $\mathrm{KPa}$. These subjects included the index subject and the other more highly exposed subjects in the study (average total exposure 137 grade-months). There was no relation between exposure and rate of change of pulmonary function. Gas transfer in the index subject had fallen from $4.1 \mathrm{ml} / \mathrm{min} / \mathrm{KPa}$ to $2.6 \mathrm{ml} / \mathrm{min} / \mathrm{KPa}$ over 71 months but three of the subjects $(15,16$, and 23) recorded an increase in transfer factor and as a result there was an increase in the mean gas transfer of 
Table 3 Response of hamster lungs to intratracheal instillation of artificial aluminium silicate, $\alpha$-quartz and ferrous oxide*

\begin{tabular}{|c|c|c|c|c|c|c|c|c|c|c|}
\hline \multirow[b]{2}{*}{$\begin{array}{l}\text { Lactic dehydrogenase } \\
(\mathrm{u} / \mathrm{ml})\end{array}$} & \multicolumn{2}{|c|}{ Saline } & \multirow{2}{*}{$\begin{array}{l}\begin{array}{l}\text { Dose of } \\
\text { contaminant } \\
(\mathrm{mg} / 100 \mathrm{~g})\end{array} \\
0.75 \\
3.75\end{array}$} & \multicolumn{3}{|c|}{$\alpha$-quartz } & \multicolumn{2}{|l|}{$\mathrm{Fe}_{2} \mathrm{O}_{3}$} & \multicolumn{2}{|c|}{$\begin{array}{l}\text { Aluminiun } \\
\text { silicate }\end{array}$} \\
\hline & $\begin{array}{l}19 \cdot 3 \\
19 \cdot 3\end{array}$ & $\begin{array}{l} \pm 1.0 \\
\pm 1.0\end{array}$ & & $\begin{array}{r}86.0 \\
135 \cdot 7\end{array}$ & $\begin{array}{l} \pm \\
\pm\end{array}$ & $\begin{array}{r}10 \cdot 6 \\
7 \cdot 3\end{array}$ & $\begin{array}{l}51 \cdot 4 \\
69 \cdot 1\end{array}$ & $\begin{array}{l} \pm 4 \cdot 7 \\
\pm 8 \cdot 1\end{array}$ & $\begin{array}{l}25 \cdot 6 \\
17 \cdot 9\end{array}$ & $\begin{array}{l} \pm 3.9 \\
\pm 1.5\end{array}$ \\
\hline $\begin{array}{l}\text { Albumin } \\
\text { (u/ml) }\end{array}$ & $\overline{64}$ & \pm 6 & $\begin{array}{l}0.75 \\
3.75\end{array}$ & $\overline{270} \cdot 2$ & & 416 & $\overline{432}$ & \pm 74 & $\overline{44} \cdot 7$ & \pm 8.7 \\
\hline $\begin{array}{l}\text { Macrophages } \\
\left(\times 10^{6}\right)\end{array}$ & $\begin{array}{l}6 \cdot 3 \\
6 \cdot 3\end{array}$ & $\begin{array}{l} \pm 0.5 \\
\pm 0.5\end{array}$ & $\begin{array}{l}0.75 \\
3.75\end{array}$ & $\begin{array}{l}4 \cdot 7 \\
3 \cdot 1\end{array}$ & $\begin{array}{l} \pm \\
\pm\end{array}$ & $\begin{array}{l}0 \cdot 6 \\
0 \cdot 3\end{array}$ & $\begin{array}{l}6 \cdot 3 \\
6 \cdot 3\end{array}$ & $\begin{array}{l} \pm 0.8 \\
\pm \quad 0.3\end{array}$ & $\begin{array}{l}7.5 \\
6.8\end{array}$ & $\begin{array}{l} \pm 0.8 \\
\pm 0.7\end{array}$ \\
\hline $\begin{array}{l}\text { Polymorphs } \\
\left(\times 10^{6}\right)\end{array}$ & $\begin{array}{l}1 \cdot 3 \\
1 \cdot 3\end{array}$ & $\begin{array}{l} \pm 0.8 \\
\pm 0.8\end{array}$ & $\begin{array}{l}0.75 \\
3.75\end{array}$ & $\begin{array}{l}38 \cdot 6 \\
21 \cdot 1\end{array}$ & $\begin{array}{l} \pm \\
\pm\end{array}$ & $\begin{array}{r}10 \cdot 4 \\
2 \cdot 5\end{array}$ & $\begin{array}{l}12 \cdot 0 \\
10 \cdot 3\end{array}$ & $\begin{array}{l} \pm 1.4 \\
\pm 0.7\end{array}$ & $\begin{array}{l}1 \cdot 7 \\
3 \cdot 1\end{array}$ & $\begin{array}{l} \pm 0.4 \\
\pm 1.1\end{array}$ \\
\hline $\begin{array}{l}\text { Red blood cells } \\
\left(\times 10^{6}\right)\end{array}$ & $\overline{9} \cdot 5$ & $\pm 1 \cdot 5$ & $\begin{array}{l}0.75 \\
3.75\end{array}$ & $\overline{334.5}$ & \pm & $92 \cdot 5$ & $\overline{15.0}$ & \pm 3.0 & $\overline{6} \cdot 5$ & \pm 0.7 \\
\hline$\lambda$ Fraction gold & \multicolumn{2}{|c|}{$0.630 \pm 0.034$} & $\begin{array}{l}0.75 \\
3.75\end{array}$ & \multicolumn{2}{|c|}{$-0.249 \pm$} & 0.044 & \multicolumn{2}{|c|}{$-_{0.565 \pm 0.052}$} & \multicolumn{2}{|c|}{$\overline{0} .828+0.040$} \\
\hline
\end{tabular}

*Mean values \pm SEM.

the group. Change in lung function was not related to subjects continuing to be exposed to alumite residue. The number of subjects, however, was small.

\section{ANIMAL STUDIES}

Exposure of hamsters to a moderately high dose (3.75 $\mathrm{mg} / 100 \mathrm{~g}$ body weight) of the alumite residue did not alter the biological parameters tested in comparison with the animals exposed only to saline (table 3 ), whereas $\alpha$-quartz and iron oxide produced pronounced effects on all parameters tested that were dose related for $\mathrm{LDH}$.

\section{Discussion}

Initial concern over the possibility of pulmonary toxicity of this artificial aluminium silicate arose when the index case complained of respiratory and systemic symptoms in relation to exposure and was found to have abnormal lung function with a fall in gas transfer on inhalation challenge, and diffuse fibrosis with granulomas on lung biopsy. ${ }^{6}$ The findings in the other exposed subjects were consistent with an effect of the material on the lungs, and other reports indicated similar findings in subjects exposed to other silicates of aluminium. ${ }^{3-5}$ The present study extends the numbers of exposed subjects in the cross sectional analysis and provides limited longitudinal data on lung function. Additionally, the animal studies that have been performed do not increase the likelihood of a cause effect relation between this aluminium silicate and pulmonary fibrosis. Further follow up of the more heavily exposed subjects may provide additional useful information, especially if histology were to become avail- able at some stage. This study has shown a statistically significant effect of current smoking status on $T_{L} V_{A}$, consistent with many others.'

Some alternative explanation for the radiographic and lung function changes in subjects $18,21,24$, and 31 is required. Although the pattern of functional changes in these subjects was not suggestive of emphysema in that airflow obstruction and overinflation were not present, all these subjects were current cigarette smokers. Gas transfer is known to be a sensitive test for destruction of alveolar walls and routine measurements may also be reduced by the presence of circulating carboxyhaemoglobin. ${ }^{9}$ Smoking may also give rise to diffuse shadowing on the chest radiograph."

Exposure categories in this and the previous report ${ }^{6}$ have been based on histories provided by the employees and may not accurately reflect relative severity. Dust concentrations were not measured in this plant because the dust was considered to be inert. Therefore calculations based on exposure categories may be incorrect, although there seems little doubt that subjects working on the bagging machine in the early days of the industry were most heavily exposed. Only one of these subjects (the index case) appears to have developed progressive lung disease. An alternative explanation for disease in the other subjects (smoking, for example) may exist.

We are grateful to Dr A E Tribe for permission to study his patient and Dr K E Finucane for performing the pulmonary function studies. Secretarial help was provided by Ms E Bingle. 


\section{References}

1 Parkes WR. Occupational lung disorders. 2nd ed. London: Butterworths, 1982:311-8.

2 Morgan WK, Seaton A. Occupational lung diseases. 2nd ed. London: WB Saunders Co, 1984.

3 Sakula A. Pneumoconiosis due to fuller's earth. Thorax 1961;16:176-9.

4 Jotten $\mathrm{KW}$, Eickoff $\mathrm{W}$. Lungen veranderungen durch sillimanitstraub. Archiv für Gewerbepathologie und Gewerbehygiene 1944;12:223-32.

5 Sherwin RP. Silicate pneumoconiosis of farm workers. Lab Invest 1979;40:576-82.

6 Musk AW, Greville HW, Tribe AE. Pulmonary disease from occupational exposure to an artificial aluminium silicate used for cat litter. Br J Ind Med 1980;37:367-72.
7 Ogilvie CM, Forster RE, Blackmore WS, Morton JW. A standardized breath-holding technique for the clinical measurement of the diffusing capacity of the $1 \mathrm{mg}$ for carbon monoxide. J Clin Invest 1975;36:1-12.

8 Dubois AB, Boteho SY, Bedell GN, Marshall R, Comroe JH. A rapid plethysmographic method for measuring thoracic gas volume: a comparison with nitrogen washout method for measuring functional residual capacity in normal subjects. $J$ Clin Invest 1956;35:322-6.

9 Cotes JE. Lung function. Assessment and application in medicine. 4th ed. Oxford: Blackwell Scientific Publications, 1979.

10 Beck BD, Brain JD, Bohannon DE. An in vivo hamster bioassay to assess toxicity of particulates for the lungs. Toxicol Appl Pharmacol 1982;66:9-29.

11 Macklem PT, Thurlbeck WM, Fraser RG. Chronic destructive disease of small airways. Ann Intern Med 1971;94:167-74.

\section{Vancouver style}

All manuscripts submitted to the $B r J$ Ind Med should conform to the uniform requirements for manuscripts submitted to biomedical journals (known as the Vancouver style)

The $\mathrm{Br} J$ Ind Med, together with many other international biomedical journals, has agreed to accept articles prepared in accordance with the Vancouver style. The style (described in full in Br Med J, 24 February 1979, p 532) is intended to standardise requirements for authors.

References should be numbered consecutively in the order in which they are first mentioned in the text by Arabic numerals above the line on each occasion the reference is cited (Manson' confirmed other reports ${ }^{2-5} \ldots$.). In future references to papers submitted to the $\mathrm{Br} J$ Ind Med should include: the names of all authors if there are six or less or, if there are more, the first three followed by et al; the title of journal articles or book chapters; the titles of journals abbreviated according to the style of Index Medicus; and the first and final page numbers of the article or chapter.

Exaniples of common forms of references are:

I International Steering Committee of Medical Editors. Uniform requirements for manuscripts submitted to biomedical journals. Br Med J 1979;1:532-5.

2 Soter NA, Wasserman SI, Austen KF. Cold urticaria: release into the circulation of histamine and eosino-phil chemotactic factor of anaphylaxis during cold challenge. $N$ Engl $J$ Med 1976;294:687-90.

3 Weinstein L. Swartz MN. Pathogenic properties of invading micro-organisms. In: Sodeman WA Jr, Sodeman WA, eds. Pathologic physiology: mechanisms of disease. Philadelphia: W B Saunders, 1974:457-72. 